\title{
SERUM PROTEIN CHANGES IN THERMAL TRAUMA. I. ELECTRO- PHORETIC ANALYSIS AT pH 8.6
}

\author{
BY GERARD F. LANCHANTIN 1 AND RUTH EDWARDS DEADRICK
}

(From the United States Army Surgical Research Unit, Brooke Army Medical Center, Fort Sam Houston, Tex.)

(Submitted for publication December 31, 1957; accepted August 4, 1958)

It is a well established fact that the circulating proteins of the human are profoundly affected by surgical, accidental and combat trauma. The medical literature on this topic emphasizes the remarkable quantitative and qualitative changes in intracellular and extracellular protein constituents occurring after and in response to injury. Fundamental information concerning these metabolic alterations as well as shifts in body water and electrolytes are of paramount importance in the development of basic concepts of treatment.

This study concerns itself with the quantitative changes in the serum electrophoretic pattern of patients who had sustained a thermal injury. Although there is a large body of literature pertaining to the alterations in the various serum electrophoretic protein components in human disease (1-4), there are relatively few reports dealing with postsurgical experiences $(5,6)$ and thermal trauma $(7,8)$.

\section{METHODS AND MATERIALS}

I. Laboratory methods. A. Collection of specimens. Blood was obtained by venipuncture of the antecubital fossa of normal individuals and from the most accessible site in burned patients. In six of the cases studied, specimens were obtained within seven hours following injury. Otherwise, all blood samples were collected in the fasting state every other day postburn and no specimens were obtained immediately after a blood transfusion or surgical procedure. All chemical and electrophoretic analyses were performed on nonhemolyzed serum. Blister bleb fluid was collected by needle aspiration and analyzed following coagulation.

B. Analysis of serum total protein. Serum protein was measured by the Biuret method of Wolfson and Cohn (9).

C. Moving-boundary electrophoresis. In preliminary studies, some of which will be mentioned herein, sera were analyzed by moving-boundary electrophoresis at $\mathrm{pH} 8.6$ in the Tiselius Apparatus according to methods

1 Present address : Biochemistry Department, Cedars of Lebanon Hospital, Los Angeles, Calif. outlined by Reiner, Fenichel and Stern (10). Several electrophoretic measurements were also carried out in acetate buffer pH 4.5 in the same system (11). In general, filter paper electrophoresis was found to be better adapted to this type of study because of the difficulty in obtaining blood from severely burned patients and this technique was employed throughout the major portion of this investigation.

D. Filter paper electrophoresis. Sera were analyzed by electrophoretic separation on filter paper in veronal buffer at $\mathrm{pH} 8.6$ for 16 hours using a Spinco Model M Apparatus. Details of the method as well as the procedure used in dying the paper strips are available elsewhere (12). The dye stained strips were scanned with a Spinco Model RA Analytrol Densitometer and the per cent composition of the electrophoretic components calculated from the tracings of the automatic integrator. The per cent composition of each serum fraction was then multiplied by the serum total protein level to obtain an estimate of the protein concentration of each component. No correction was made for albumin "trailing" or differences in dye binding capacity of the various fractions. A statistical analysis of replicate serum specimens obtained from normal individuals and burned patients demonstrated a reproducibility consistent with that reported by others (13) using this method. The mean concentration and standard deviation (in gram per cent) for serum total protein and the electrophoretic components of sera collected from 25 young military personnel in good health were as follows: albumin, $3.4 \pm 0.2$; alpha-1 globulin, $0.38 \pm 0.03$; alpha- 2 globulin, $0.83 \pm 0.18$; beta globulin, $1.01 \pm 0.2$; gamma globulin, $1.45 \pm 0.25$; $^{2}$ total protein, $7.04 \pm 0.16$.

II. Clinical material. A summary of the pertinent clinical features of the patients studied in this investigation is presented in Table I. Cases have been tabulated in order of increasing burn severity as estimated on the basis of the burn index. The burn index (B.I.) was

2 When the normal equivalent deviate (14) was plotted against the concentrations of each set of individual components, the alpha-2 and gamma globulin components were found to present a curve of positive skewness indicating non-normal distribution. A similar finding was obtained with the moving-boundary data. This is perhaps not surprising in view of the fact that a large series of serum total globulin determinations on healthy individuals demonstrated non-normal distribution (15). 
TABLE I

Summary of cases studied

\begin{tabular}{|c|c|c|c|c|c|c|c|}
\hline \multirow{2}{*}{$\begin{array}{c}\text { Patient } \\
\text { no. }\end{array}$} & \multirow[b]{2}{*}{ Sex } & \multirow[b]{2}{*}{ Age } & \multirow{2}{*}{$\underset{\text { index* }}{\text { Burn }}$} & \multicolumn{2}{|c|}{ Per cent burn $\dagger$} & \multirow[b]{2}{*}{ Survivalt } & \multirow[b]{2}{*}{ Remarks } \\
\hline & & & & Total & 3rd & & \\
\hline \multicolumn{8}{|l|}{ Group I } \\
\hline $\begin{array}{l}1 \\
2 \\
3 \\
4 \\
5 \\
6 \\
7\end{array}$ & $\begin{array}{l}\mathbf{M} \\
\mathbf{M} \\
\mathbf{M} \\
\mathbf{M} \\
\mathbf{M} \\
\mathbf{F} \\
\mathbf{M}\end{array}$ & $\begin{array}{l}23 \\
21 \\
21 \\
24 \\
21 \\
35 \\
36\end{array}$ & $\begin{array}{r}2 \\
3 \\
4 \\
6 \\
7 \\
8 \\
10\end{array}$ & $\begin{array}{r}7 \\
13 \\
15 \\
7 \\
13 \\
15 \\
10\end{array}$ & $\begin{array}{r}0 \\
0 \\
0 \\
5 \\
5 \\
5 \\
10\end{array}$ & $\begin{array}{l}\mathbf{S} \\
\mathbf{S} \\
\mathbf{S} \\
\mathbf{S} \\
\mathbf{S} \\
\mathbf{S} \\
\mathbf{S}\end{array}$ & Electrical burn \\
\hline \multicolumn{8}{|c|}{ Group II } \\
\hline $\begin{array}{r}8 \\
9 \\
10 \\
11 \\
12 \\
13 \\
14 \\
15 \\
16\end{array}$ & $\begin{array}{l}\mathbf{M} \\
\mathbf{M} \\
\mathbf{M} \\
\mathbf{M} \\
\mathbf{F} \\
\mathbf{M} \\
\mathbf{M} \\
\mathbf{M} \\
\mathbf{M}\end{array}$ & $\begin{array}{l}32 \\
21 \\
23 \\
49 \\
57 \\
31 \\
18 \\
24 \\
23\end{array}$ & $\begin{array}{l}12 \\
13 \\
13 \\
14 \\
16 \\
17 \\
18 \\
20 \\
21\end{array}$ & $\begin{array}{l}19 \\
25 \\
25 \\
27 \\
24 \\
22 \\
35 \\
31 \\
38\end{array}$ & $\begin{array}{r}9 \\
9 \\
9 \\
10 \\
13 \\
15 \\
12 \\
16 \\
15\end{array}$ & $\begin{array}{l}\mathbf{S} \\
\mathbf{S} \\
\mathbf{S} \\
\mathbf{E} \\
\mathbf{S} \\
\mathbf{S} \\
\mathbf{S} \\
\mathbf{S} \\
\mathbf{S}\end{array}$ & $\begin{array}{l}\text { Fractured humerus } \\
\text { Homologous serum jaundice } \\
\text { Hepatic parenchymal degeneration }\end{array}$ \\
\hline \multicolumn{8}{|c|}{ Group III } \\
\hline $\begin{array}{l}17 \\
18 \\
19 \\
20\end{array}$ & $\begin{array}{l}\mathbf{M} \\
\mathbf{M} \\
\mathbf{M}\end{array}$ & $\begin{array}{l}26 \\
18 \\
20 \\
21\end{array}$ & $\begin{array}{l}24 \\
25 \\
30 \\
33\end{array}$ & $\begin{array}{l}54 \\
47 \\
45 \\
39\end{array}$ & $\begin{array}{l}17 \\
18 \\
25 \\
31\end{array}$ & $\begin{array}{l}\mathbf{S} \\
\mathbf{S} \\
\mathbf{S}\end{array}$ & $\begin{array}{l}\text { Proven septicemia } \\
\text { Proven septicemia } \\
\text { Curling's ulcer }\end{array}$ \\
\hline $\begin{array}{l}21 \\
22 \\
23 \\
24\end{array}$ & $\begin{array}{l}\mathbf{M} \\
\mathbf{M} \\
\mathbf{F}\end{array}$ & $\begin{array}{l}59 \\
34 \\
23 \\
17\end{array}$ & $\begin{array}{l}34 \\
34 \\
36 \\
38\end{array}$ & $\begin{array}{l}44 \\
45 \\
55 \\
82\end{array}$ & $\begin{array}{l}31 \\
30 \\
29 \\
20\end{array}$ & $\begin{array}{l}\mathrm{E} \\
\mathrm{S} \\
\mathrm{E} \\
\mathrm{E}\end{array}$ & $\begin{array}{l}\text { Clinical septicemia } \\
\text { Thrombophlebitis } \\
\text { Clinical septicemia } \\
\text { Proven septicemia } \\
\text { Curling's ulcer }\end{array}$ \\
\hline $\begin{array}{l}25 \\
26 \\
27 \\
28\end{array}$ & $\begin{array}{l}\mathbf{M} \\
\mathbf{M} \\
\mathbf{M} \\
\mathbf{M}\end{array}$ & $\begin{array}{l}21 \\
19 \\
36 \\
24\end{array}$ & $\begin{array}{l}41 \\
45 \\
48 \\
53\end{array}$ & $\begin{array}{l}42 \\
63 \\
55 \\
69\end{array}$ & $\begin{array}{l}40 \\
39 \\
45 \\
48\end{array}$ & $\begin{array}{l}\mathrm{S} \\
\mathbf{S} \\
\mathrm{E}\end{array}$ & $\begin{array}{l}\text { Clinical septicemia } \\
\text { Proven septicemia } \\
\text { Proven septicemia } \\
\text { Septicemia }\end{array}$ \\
\hline
\end{tabular}

* B.I. = per cent area third degree burn $+1 / 4$ area second degree burn.

$\dagger$ All estimates of per cent and area of burn are final estimations.

$\ddagger S$, survived; $E$, expired.

calculated in a manner similar to that of Bull and Squire (16) by the formula :

B.I. = per cent area third degree burn

$+1 / 4$ area second degree burn.

This formula has been used in similar studies of serum protein levels in burns (17) and has been demonstrated to be the best index in the evaluation of the nitrogen metabolism following thermal injury (18).

The per cent of burn area was estimated clinically by the rule of nines (19) in which the body surface is divided into areas representing 9 per cent or multiples of 9 per cent: the head and neck, 9 per cent; anterior trunk, $2 \times 9$ or 18 per cent; posterior trunk, 18 per cent; each lower extremity, 18 per cent; each upper extremity, 9 per cent; and the perineum, 1 per cent. Since initial estimates of burn involvement are commonly overestimated, all values given are based on the final estimation of the patient's injury after excision, grafting, and so forth.
For purposes of tabulation and discussion, the patients listed in Table I have been arbitrarily broken down into three groups. Group I includes those patients who sustained a third degree injury of less than 10 per cent and whose B.I. was less than 10. Group II consisted of nine patients having a range in B.I. of 12 to 21 . Cases in Group III were the most severely injured, having a range in B.I. of 24 to 53 . Of these 12 cases, 9 had proven or clinical septicemia (75 per cent) and 6 expired (50 per cent). All patients were studied within a 10 month period so that established methods of treatment were essentially similar in each case (20).

\section{RESULTS}

Figures 1 through 4 present data on the alterations of the serum levels of total protein and electrophoretic components of 14 patients who had sustained a third degree thermal injury of greater 


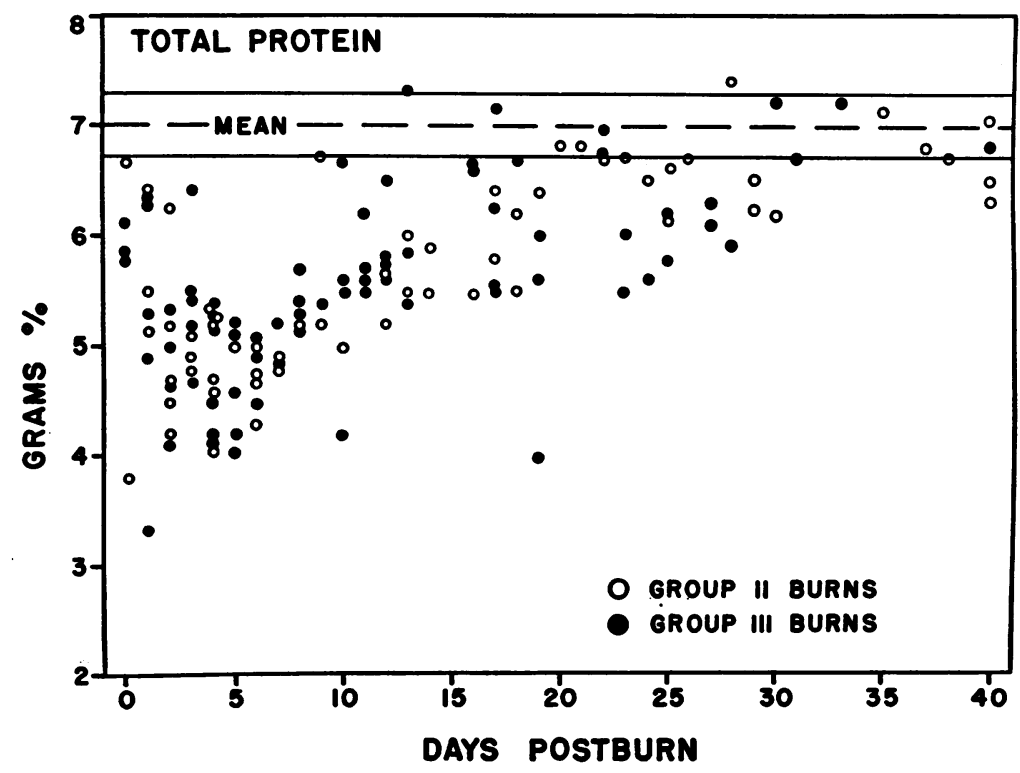

Fig. 1. Serum Total Protein Levels Following Thermal Injury

The dashed horizontal line represents the mean of normal values (see text). The solid horizontal lines represent two standard deviations from the mean. Day 0 postburn is the day of injury. The individual tabulation of each burn group is presented in Table I.

than 12 per cent of the body surface. Albumin and alpha-2 globulin levels on 4 less severely burned patients (Group I patients) are included in Figures 2 and 3. Values obtaind on Day 0 represent the first serum specimen drawn after the injury. Otherwise, all values were obtained on specimens collected each morning on the day indicated in the figures.

From the data presented in Figure 1, it is seen that there is a sharp reduction in the serum total protein level in the immediate postburn period. Although analyses were performed on six patients, within 45 minutes to seven hours after injury, there was no evidence of serum hyperproteinemia immediately after the burn as has previously been reported by others (21). At about the first to the fifth day, the serum total protein level in the majority of patients was in the neighborhood of $5 \mathrm{Gm}$. per cent, irrespective of the severity of the burn. This observation has also been made by others (20) on patients under similar therapy at this Unit where fluid and electrolyte administration in the immediate postburn period is emphasized.

That the decrease in albumin is mainly respon- sible for the initial fall in serum total protein concentration is indicated in Figure 4. However, percentage-wise, many of the electrophoretic patterns were normal at Day 0 or Day 1 indicating that secondary dilution from shifts of water to vascular spaces as well as fluid therapy also account for low levels of circulating protein. From Day 2 to 5 , the decreased level of albumin is almost wholly responsible for the low total protein since during this time several of the other serum protein components are normal or elevated. Between Day 5 and 6, albumin concentration reaches a minimum and remains at a very low level in most instances for two to three months following a burn. Serum total protein on the other hand, gradually starts to increase toward normal levels about Day 6. Inspection of the changes in globulin components (Figures 3 and 4 ) indicates that this increase in total protein level is due to an increase in certain of the globulin components, particularly gamma globulin and alpha-2 globulin which constitute the majority of the globulin fraction.

In Figure 3, the comparatively rapid increase in the alpha globulins beginning about the second 


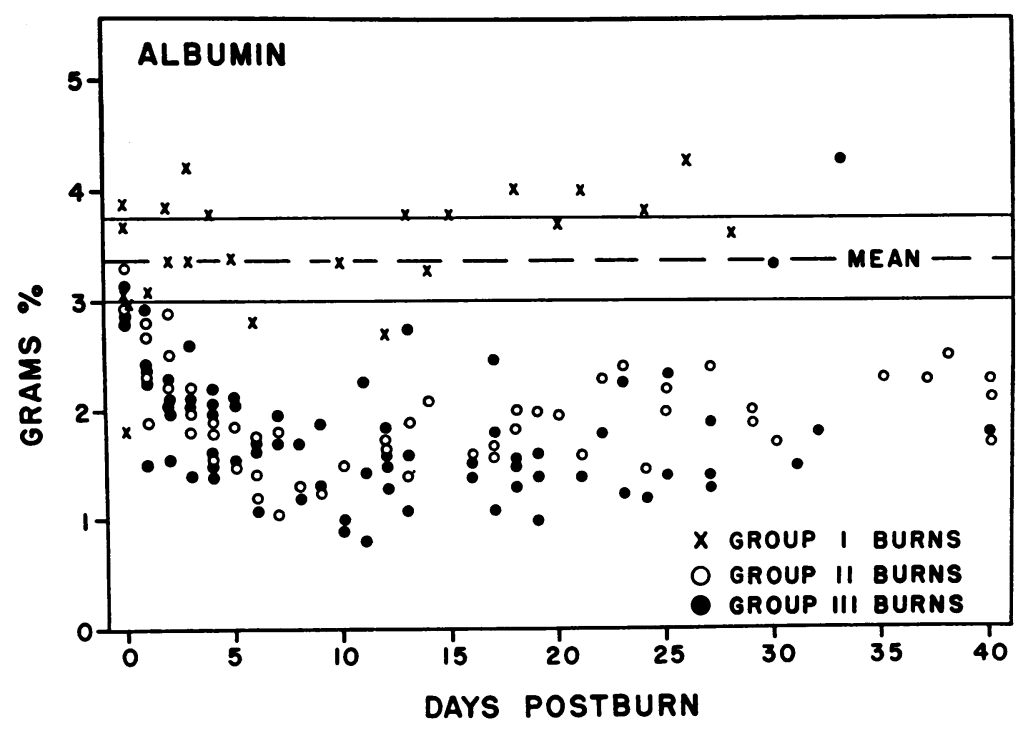

Fig. 2. Serum Albumin Levels Following Thermal Injury See Figure 1 for explanation.

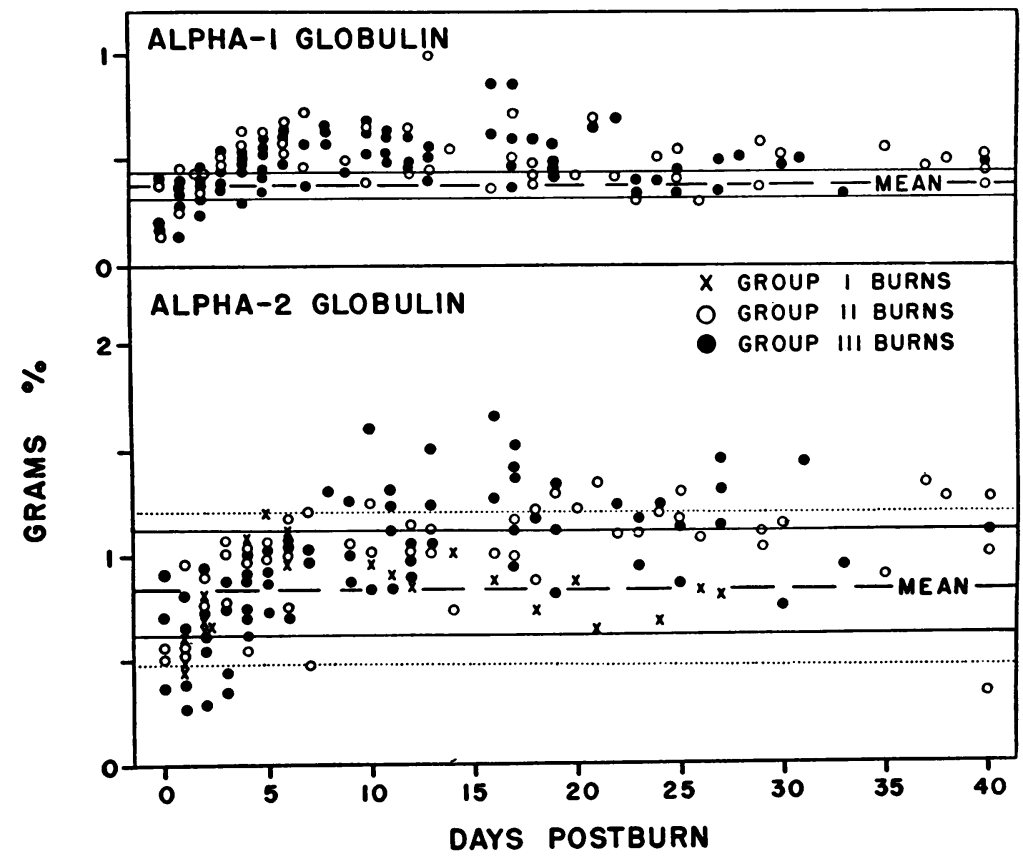

Fig. 3. Serum Alpha-1 and Alpha-2 Globulins Following Thermal INJURY

See Figure 1 for explanation. The dotted horizontal line on either side of the normal mean of alpha-2 globulin represents the range of values in normal humans.

postburn day is indicated. The accurate electrophoretic quantitation of alpha-1 globulin is difficult due to its comparatively low concentration and dependence upon separation from albumin. However, in spite of considerable variation, the data presented in Figure 3 indicate that alpha-1 


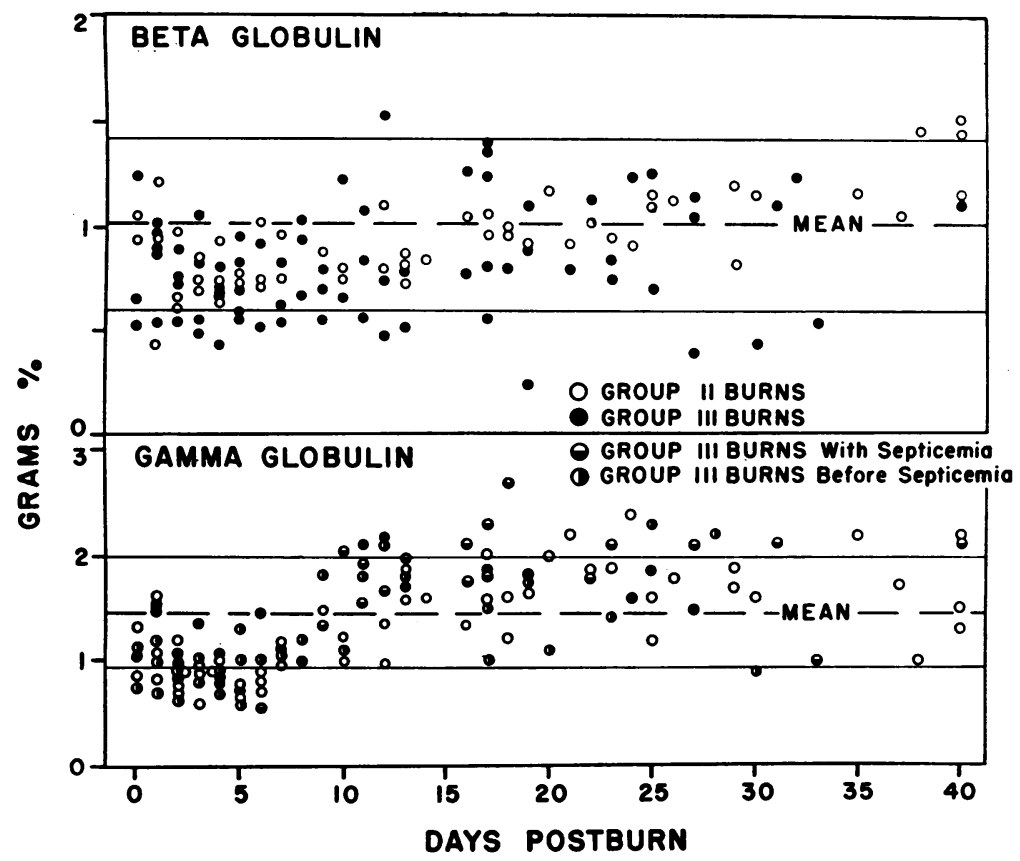

Fig. 4. Serum Beta and Gamma Globulins Following Thermal INJURY

See Figure 1 for explanation.

globulin parallels the level of alpha-2 globulin following the thermal injury.

Sera obtained routinely from six patients were analyzed at $\mathrm{pH} 4.5$ in the Tiselius apparatus (11). At this $\mathrm{pH}$ the majority of the serum proteins are positively charged and migrate cathodically with the exception of the more acidic glycoproteins of the alpha globulins fraction. The glycoprotein components having a mobility of $\mathrm{M}-1$ and $\mathrm{M}-2$ as described by Mehl, Golden and Winzler (11) were found to be markedly elevated at about Days 4 to 6 following injury. Similar findings have been obtained by chemical and immunological methods $(22,23)$ which appear to suggest that increases in the glycoprotein concentrates following injury are partially responsible for the increase in alpha globulin components of serum. Increases in alpha globulin occur in a variety of wasting diseases and in most instances of hypoalbuminemia. High levels of alpha-2 globulin have previously been reported in burns $(7,8,24)$ although there is no information on alpha-1 globulin changes. It thus appears evident that in many types of stress including burns, increase in alpha- globulin components occurs irrespective of the type of injury sustained (25).

Very little evidence was obtained that any change takes place in the level of the beta globulins following a burn (Figure 4). With the exception of a few instances in which this component was slightly decreased in the immediate postburn period, no radical change in beta globulin was noted by either filter paper or moving-boundary electrophoretic techniques. This is perhaps a little surprising in view of the marked alterations in lipoprotein levels reported in laboratory animals following injury (24), since the beta globulin component includes the majority of these high molecular weight substances. These changes would not necessarily be evident by filter paper electrophoresis in which only protein components are detected by the protein staining procedure, but one would expect the beta globulin area as measured by the moving-boundary method to be increased. This did not occur, however.

The lack of any detectable change in the level of beta globulin lipoprotein as measured electrophoretically in the patients studied seems to indi- 


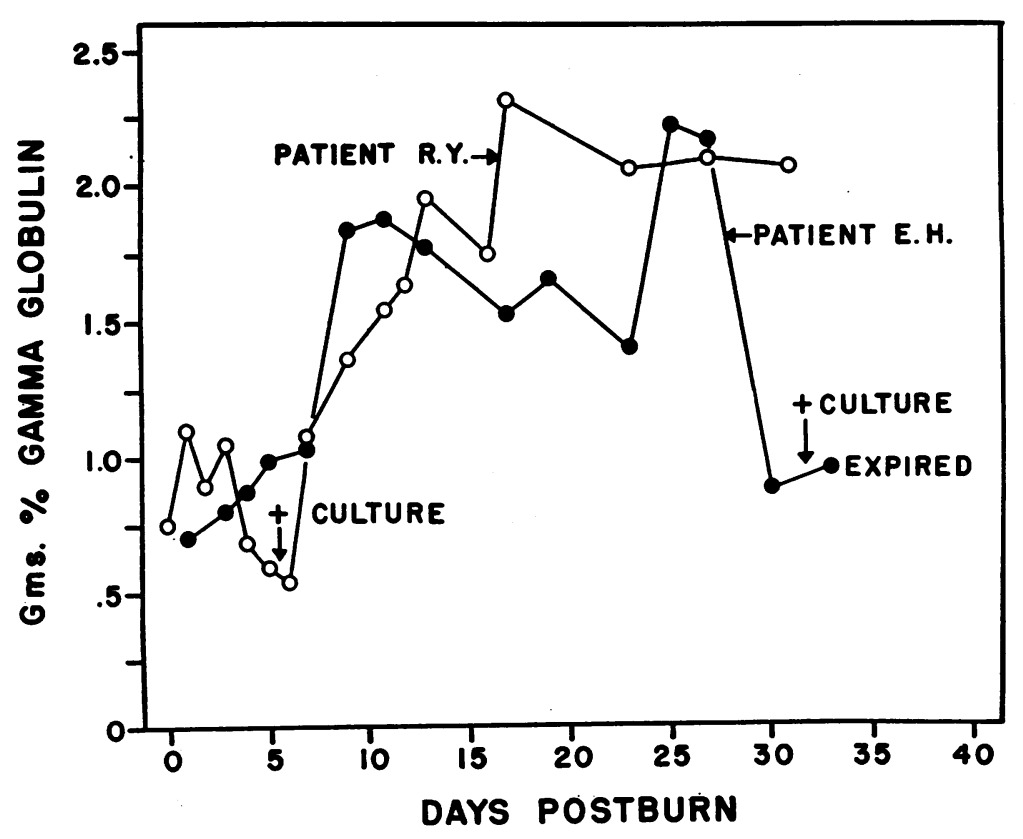

Fig. 5. An Example of the Gamma Globulin Levels in Early and Late Postburn Septicemia

Open circles, Patient 17; dark circles, Patient 22. Mean of normal serum gamma globulin, $1.45 \pm 0.51 \mathrm{Gm}$. per cent.

cate that the alterations in lipoprotein levels following injury to laboratory animals (26) may be due to changes in the alpha- 1 lipoproteins. It is entirely possible that the small increases in alpha-1 globulin protein noted in Figure 3 could be responsible for the marked changes in the lipid moiety of this component (27). However, such an interpretation is difficult because of the separate properties of lipoproteins which are measured by electrophoretic, ultracentrifugal and chemical techniques.

The second half of Figure 4 presents the levels of serum gamma globulin in Group II and Group III patients following a burn. Since there was no significant deviation from the normal range in Group I patients, these data were not included in the figure.

Following thermal injury, there appears to be a tendency toward hypogammaglobulinemia during the first six days postburn irrespective of the extent of the burn. The initial reduction of gamma globulin followed by an increase in this component above the normal range at about the second week following injury took place in almost every burn case studied. No particular relation- ship could be found between the change in level of gamma globulin following injury and the predisposal or occurrence of septicemia in the patients studied. However, it was noted that in four patients with septicemia in whom gamma globulin data were collected at about the time of a positive blood culture or onset of symptoms, the level of gamma globulin appeared to be abnormally low. An example of the gamma globulin level in two such patients, one with early septicemia and one with late septicemia, is presented in Figure 5.

The present study supports the observations of Balikov, Artz and Solometo who noted a tendency toward post-traumatic hypogammaglobulinemia in a study of 19 burn patients admitted to the Clinical Division of this Unit (17). These workers drew attention to the fact that patients with a B.I. greater than $\mathbf{5}$ usually had a gamma globulin level that was low both in concentration and in per cent of the total serum protein. It is interesting to note that although their technique and normal values for gamma globulin were different from the present study, the observed results were essentially similar (Figure 4). 
TABLE II

Comparison of the distribution of electrophoretic components in serum and blister fluid (BF) collected simultaneously in the same patient

\begin{tabular}{|c|c|c|c|c|c|c|c|c|c|}
\hline \multirow[b]{2}{*}{ Patient } & \multirow[b]{2}{*}{ Specimen } & \multirow[b]{2}{*}{ Site } & \multirow[b]{2}{*}{ T.P.* } & \multirow[b]{2}{*}{ Method $\dagger$} & \multirow[b]{2}{*}{ Alb. } & \multicolumn{4}{|c|}{ Per cent distribution } \\
\hline & & & & & & Alpha-1 & Alpha-2 & Beta & Gamma \\
\hline 1 & $\begin{array}{l}\text { BF } \\
\text { Serum }\end{array}$ & Arm & $\begin{array}{c}\text { Gm. } \% \\
4.2 \\
5.3\end{array}$ & $\begin{array}{l}\text { FP } \\
\text { FP }\end{array}$ & $\begin{array}{l}59.1 \\
55.9\end{array}$ & $\begin{array}{l}8.3 \\
2.8\end{array}$ & $\begin{array}{r}10.6 \\
8.9\end{array}$ & $\begin{array}{l}12.9 \\
15.1\end{array}$ & $\begin{array}{r}9.1 \\
17.3\end{array}$ \\
\hline 2 & $\begin{array}{l}\text { BF } \\
\text { Serum }\end{array}$ & Arm & $\begin{array}{l}5.3 \\
6.9\end{array}$ & $\begin{array}{l}\text { FP } \\
\text { FP }\end{array}$ & $\begin{array}{l}66.0 \\
49.3\end{array}$ & $\begin{array}{l}5.8 \\
5.6\end{array}$ & $\begin{array}{r}5.8 \\
15.0\end{array}$ & $\begin{array}{r}9.0 \\
12.4\end{array}$ & $\begin{array}{l}13.5 \\
17.7\end{array}$ \\
\hline 9 & $\begin{array}{l}\text { BF } \\
\text { BF } \\
\text { Serum }\end{array}$ & $\begin{array}{l}\text { Rt. leg } \\
\text { Lt. leg }\end{array}$ & 3.9 & $\begin{array}{l}\text { MB } \\
\text { FP } \\
\text { MB } \\
\text { FP } \\
\text { FP }\end{array}$ & $\begin{array}{l}57.4 \\
57.5 \\
60.2 \\
54.1 \\
36.5\end{array}$ & $\begin{array}{r}7.7 \\
7.5 \\
6.5 \\
7.4 \\
12.8\end{array}$ & $\begin{array}{r}9.1 \\
9.2 \\
9.7 \\
7.4 \\
22.3\end{array}$ & $\begin{array}{r}8.3 \\
12.5 \\
9.3 \\
18.0 \\
14.9\end{array}$ & $\begin{array}{l}17.5 \\
13.3 \\
14.3 \\
13.1 \\
13.5\end{array}$ \\
\hline 11 & $\begin{array}{l}\text { BF } \\
\text { Serum }\end{array}$ & Chest & $\begin{array}{l}2.7 \\
3.8\end{array}$ & $\begin{array}{l}\text { FP } \\
\text { FP }\end{array}$ & $\begin{array}{l}59.6 \\
50.4\end{array}$ & $\begin{array}{l}6.1 \\
6.2\end{array}$ & $\begin{array}{r}8.1 \\
13.1\end{array}$ & $\begin{array}{l}13.1 \\
11.6\end{array}$ & $\begin{array}{l}13.1 \\
18.6\end{array}$ \\
\hline 16 & $\begin{array}{l}\text { BF } \\
\text { Serum }\end{array}$ & Leg & $\begin{array}{l}3.6 \\
6.4\end{array}$ & $\begin{array}{l}\text { FP } \\
\text { FP }\end{array}$ & $\begin{array}{l}54.2 \\
42.0\end{array}$ & $\begin{array}{l}8.4 \\
4.0\end{array}$ & $\begin{array}{l}7.5 \\
9.2\end{array}$ & $\begin{array}{l}16.8 \\
18.9\end{array}$ & $\begin{array}{l}13.1 \\
25.8\end{array}$ \\
\hline 22 & $\begin{array}{l}\text { BF } \\
\text { Serum }\end{array}$ & Arm & $\begin{array}{l}4.9 \\
5.8\end{array}$ & $\begin{array}{l}\text { FP } \\
\text { FP }\end{array}$ & $\begin{array}{l}58.3 \\
48.2\end{array}$ & $\begin{array}{l}4.3 \\
3.6\end{array}$ & $\begin{array}{l}6.5 \\
7.6\end{array}$ & $\begin{array}{r}13.0 \\
9.1\end{array}$ & $\begin{array}{l}18.0 \\
18.8\end{array}$ \\
\hline 28 & $\begin{array}{l}\text { BF } \\
\text { BF } \\
\text { Serum }\end{array}$ & $\begin{array}{l}\text { Rt. leg } \\
\text { Lt. leg }\end{array}$ & $\begin{array}{l}3.4 \\
3.7 \\
4.7\end{array}$ & $\begin{array}{l}\text { MB } \\
\text { FP } \\
\text { MB } \\
\text { FP } \\
\text { MB } \\
\text { FP }\end{array}$ & $\begin{array}{l}55.3 \\
54.6 \\
64.8 \\
60.0 \\
44.8 \\
33.5\end{array}$ & $\begin{array}{r}9.3 \\
11.1 \\
8.4 \\
5.2 \\
8.1 \\
11.6\end{array}$ & $\begin{array}{r}9.2 \\
3.7 \\
4.7 \\
8.7 \\
19.7 \\
18.7\end{array}$ & $\begin{array}{r}8.4 \\
10.2 \\
8.1 \\
12.2 \\
11.7 \\
14.8\end{array}$ & $\begin{array}{l}17.9 \\
20.4 \\
14.1 \\
13.9 \\
17.0 \\
21.3\end{array}$ \\
\hline
\end{tabular}

* Total protein.

† FP, filter paper; MB, moving-boundary.

\section{DISCUSSION}

A number of explanations have been offered for the hypogammaglobulinemia following burns (17). It appears from our own observations and related data in the literature, however, that this phenomenon can be explained on the basis of shifts in body water and the resulting dilution of protein following burns.

Plasma protein circulating in the vascular network is diminished following a burn due to withdrawal of water from unburned tissue and an increase in capillary permeability $(21,28)$. These effects would be responsible for the reduction in total protein and the various electrophoretic components in thermally injured laboratory animals $(29,30)$ who have received no treatment and probably to a greater extent in humans receiving fluid therapy. The interstitial space in moderate and severe burns increases quite markedly following a burn, even in adequately treated patients (31). That this body compartment is re- sponsible for trapping the protein lost from the vascular compartment is demonstrated by the fact that lymph draining from the burn area shows an increased protein content (32). Although such lymph shows a preponderance of albumin over that in serum, it also contains appreciable globulin (21) and indicates the large concentration of this fraction dissolved in interstitial water. An analysis of blister blebs (which can be regarded as interstitial fluid) in seven of the patients in this study amply confirms this fact (Table II). It will be noted in the table that in each instance the per cent distribution of albumin is greater than that for globulin. This might be expected since the transfer rates from vascular to extravascular space in the normal is slightly greater for albumin than gamma globulin (33). However, in spite of the differential permeability to albumin, the globulin concentration is quite appreciable when one considers the expanded interstitial volume in which it is dissolved. It is this abnormally distended plasma protein reser- 
voir which is responsible for the low total protein level existing in the plasma immediately following a burn. This might be expected to be obtained even in normal persons undergoing fluid infusions $(33,34)$.

Figure 6 presents a three dimensional diagram of the mean levels of the various filter paper electrophoretic components of 14 patients following thermal injury. What appears to be a selective reduction in gamma globulin during the first six days following a burn may actually be the result of several factors. The alpha globulins have a very high turnover rate (35) and are apparently rapidly mobilized by the liver in response to stress (25). As a result, at about the third postburn day gamma globulin appears depressed in relation to the alpha globulins which have returned to normal levels or are elevated. From the fifth to the sixth postburn day, diuresis usually occurs in burned patients (36). It will be noted in Figure 6 that this is the time during which gamma globulin returns to normal levels and subsequently overcompensates for its previous low level. The rate of reinfusion of protein from interstitial to vascular compartments during this time is probably different from what it was from vascular to interstitial (37). This is known to be particularly so for gamma globulin from acute plasmapherisis experiments (38).

From the foregoing remarks it appears entirely plausible that the shifts in gamma globulin following burns can be explained on the basis of shifts in body water and to some extent dilution. Certainly this appears the most obvious answer. The relationship between the gamma globulin level and septicemia is not clear. Only a small percentage of gamma globulin represents antibody protein (39) and it would appear that burn patients have a normal total body gamma globulin although of different distribution from that found in healthy individuals.

\section{SUMMARY}

This study concerned itself with the quantitative changes in the serum electrophoretic pattern of 28 patients who had sustained a thermal injury. The methods utilized included moving-boundary and filter paper electrophoresis at $\mathrm{pH}$ 8.6. The latter technique was found to be more adaptable

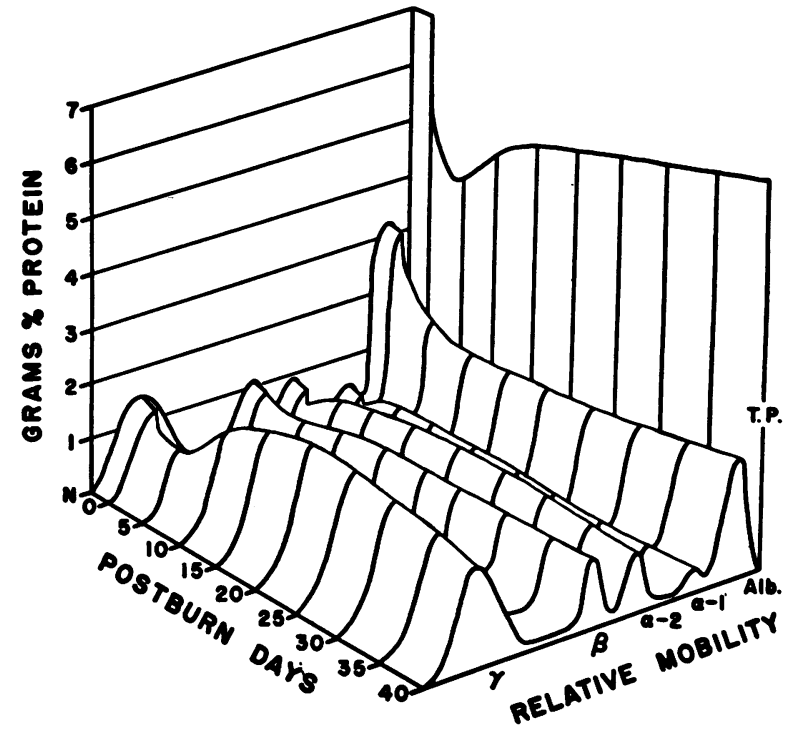

Fig. 6. Summary of Distribution of Serum Electrophoretic Components and Total Protein Following Thermal Injury of Patients in Group II and GrouP III (TABLE I)

to this type of study and as a result, the data obtained on 18 patients using this method are presented in more detail.

Following thermal injury having a burn index of less than 10 there is little evidence that any marked or definite change takes place in any of the serum components. Above this burn index, i.e., greater than 12 , however, the pattern presented with time postburn appears to result irrespective of the area or severity of the injury. The changes in each of these electrophoretic components with time following injury are discussed in relation to underlying biochemical mechanisms.

No particular relationship was noted between the extent of hypogammaglobulinemia following injury and either the predisposal or occurrence of septicemia. Although there was some evidence (four patients) that septicemia occurred at a time of hypogammaglobulinemia, the data are insufficient to permit any conclusion. A reduction in gamma globulin following injury occurred to some extent in every patient with a burn index greater than 10 and it is suggested that this phenomenon is the result of a shift in the compartmentalization of this component.

No alteration was noted in the beta globulin component following injury. However, the lack 
of any observed change in this component may be due to the method of analysis employed.

\section{REFERENCES}

1. Leutscher, J. A., Jr. Biological and medical applications of electrophoresis. Physiol. Rev. 1947, 27, 621.

2. Gutman, A. B. The plasma proteins in disease. Advanc. Protein Chem. 1948, 4, 155.

3. Henley, A., and Schuettler, C. L. Electrophoresis Bibliography. Silver Spring, Md, American Instrument Company, 1955.

4. Fisher, B. Recent contributions of electrophoresis to clinical pathology. Amer. J. clin. Path. 1953, 23, 246.

5. Margulis, R. R., Wiseman, M. E., Moyer, E. Z., and Pratt, J. P. Changes in the electrophoretic pattern of the plasma proteins as induced by surgery in Surg. Forum (38th Clin. Cong. Amer. Coll. Surgeons, 1952). Philadelphia, Pa., W. B. Saunders, 1953 , p. 571.

6. Baar, S., and Topley, E. Haemoglobin metabolism and serum proteins following trauma. Acta med. scand. 1956, 153, 319.

7. Shedlovsky, T., and Scudder, J. A comparison of erythrocyte sedimentation rates and electrophoretic patterns of normal and pathological human blood. J. exp. Med. 1942, 75, 119.

8. Prendergast, J. J., Fenichel, R. L., and Daly, B. M. Albumin and globulin changes in burns as demonstrated by electrophoresis. Arch. Surg. (Chicago) 1952, 64, 733.

9. Wolfson, W. Q., and Cohn, C. Rapid Chemical Micromethods for the Analytic Fractionation of Serum Proteins. Ann Arbor, Mich., The Oberbeck Company, 1951, p. 4.

10. Reiner, M., Fenichel, R. L., and Stern, K. G. Electrophoretic studies on the protein distribution in normal human serum. Acta Haemat. (Basel) 1950, 3, 202.

11. Mehl, J. W., Golden, F., and Winzler, R. J. Mucoproteins of human plasma. IV. Electrophoretic demonstration of mucoproteins in serum at $\mathrm{pH}$ 4.5. Proc. Soc. exp. Biol. (N. Y.) 1949, 72, 110.

12. Jencks, W. P., Jetton, M. R., and Durrum, E. L. Paper electrophoresis as a quantitative method. Serum proteins. Biochem. J. 1955, 60, 205.

13. Henry, R. J., Golub, O. J., and Sobel, C. Some of the variables involved in the fractionation of serum proteins by paper electrophoresis. Clin. Chem. 1957, 3, 49.

14. Moore, F. J., Cramer, F. B., and Knowles, R. G. Statistics for Medical Students. New York, The Blakiston Company, 1951, p. 103.

15. Wootton, I. D. P., King, E. J., and Smith, J. M. Measurement in medicine; the quantitative approach to hospital biochemistry; normal values and use of biochemical determinations for diagnosis and prognosis. Brit. med. Bull. 1951, 7, 307.
16. Bull, J. P., and Squire, J. R. A study of mortality in a burns unit. Ann. Surg. 1949, 130, 160.

17. Balikov, B., Artz, C. P., and Solometo, D. F. Serum gamma globulin in the burned patient, with special reference to septicemia. U. S. armed Forces med. J. 1957, 8, 321.

18. Schwartz, M. S., Soroff, H. S., Reiss, E., and Artz, C. P. An evaluation of the mortality and the relative severity of second and third degree injuries in burns. U. S. Army Surgical Research Unit Rept., Dec., 1956.

19. Pulaski, E. J., Artz, C. P., Shaeffer, J. R., Huckabee, W. E., Mitchell, R. C., and Russell, J. P. Exposure (open) treatment of burns. U. S. armed Forces med. J. 1951, 2, 769.

20. Reiss, E., Stirman, J. A., Artz, C. P., Davis, J. H., and Amspacher, W. H. Fluid and electrolyte balance in burns. J. Amer. med. Ass. 1953, 152, 1309.

21. Cope, O., Graham, J. B., Moore, F. D., and Ball, M. R. The nature of the shift of plasma protein to the extravascular space following thermal trauma. Ann. Surg. 1948, 128, 1041.

22. Lanchantin, G. F., Morico, J. L., and Tausig, F. Serum protein changes in thermal trauma. IV. Some quantitative and qualitative aspects of total serum glycoprotein and seromucoid following burns. U. S. Army Surgical Research Unit Rept., June, 1957.

23. Glenn, W. G., Lanchantin, G. F., Mitchell, R. B., and Marable, I. W. Normal and abnormal humanantihuman precipitin reactions in agar columns. School of Aviation Medicine USAF Rept. No. 5832, Jan., 1958.

24. Largot, F., Antoine, G., and Césaire, G. Les altérations electrophorétiques observées chez les brulés. Presse méd. 1955, 63, 762.

25. Roberts, S., and White, A. Studies on the origin of the serum proteins. J. biol. Chem. 1949, 180, 505.

26. Milch, L. J., Redmond, R. F., and Calhoun, W. W. Blood lipoproteins in traumatic injury. J. Lab. clin. Med. 1954, 43, 603.

27. Oncley, J. L., and Gurd, F. R. N. Lipoproteins of human plasma in Blood Cells and Plasma Proteins, J. L. Tullis, Ed. New York, Academic Press Inc., 1953, p. 337.

28. Lund, C. C., Green, R. W., Taylor, F. H. L., and Levenson, S. M. Burns: Collective review. Int. Abstr. Surg. 1946, 82, 443.

29. Gjessing, E. C., Ludewig, S., and Chanutin, A. Fractionation, electrophoresis and chemical studies of proteins in sera of control and injured dogs. J. biol. Chem. 1947, 170, 551.

30. Chanutin, A., and Gjessing, E. C. Electrophoretic analyses of sera of injured dogs. J. biol. Chem. 1946, 165, 421.

31. Cope, O., and Moore, F. D. The redistribution of body water and the fluid therapy of the burned patient. Ann. Surg. 1947, 126. 1010. 
32. Field, M. E., Drinker, C. K., and White, J. C. Lymph pressures in sterile inflammation. J. exp. Med. 1932, 56, 363.

33. Slater, R. J., and Sass-Kortsak, A. The turnover and circulation of the plasma proteins in the body. Amer. J. med. Sci. 1956, $231,669$.

34. Korner, P. I., Morris, B., and Courtice, F. C. An analysis of factors affecting lymph flow and protein composition during gastric absorption of food and fluids, and during intravenous infusion. Aust. J. exp. Biol. med. Sci. 1954, 32, 301.

35. Miller, L. L., and Bale, W. F. Synthesis of all plasma protein fractions except gamma globulin by the liver. J. exp. Med. 1954, 99, 125.
36. Artz, C. P., and Reiss, E. The Treatment of Burns. Philadelphia, W. B. Saunders Company, 1957, p. 24.

37. Harrison, C. S., and Becker, J. M. Sucrose space determinations in thermally injured animals; evaluation with use of the lymphatic cannulation technique. A. M. A. Arch. Surg. 1956, 73, 747.

38. Thorbecke, G. J., and Keuning, F. J. Antibody and gamma globulin formation in vitro in hemopoietic organs. J. infect. Dis. 1956, 98, 157.

39. Oncley, J. L. Physical characteristics of the gamma globulins in Blood Cells and Plasma Proteins, J. L. Tullis, Ed. New York, Academic Press Inc., 1953, p. 180. 